Lólé Bianka

\title{
Gondolatok Markos ValérIa kÖNYVÉRőL ${ }^{1}$
}

\author{
DOI 10.35402/kek.2021.2.21
}

Számomra, ahogy a Szerző számára is elgondolkodtató, hogy ebben a rohanó világban mire elég 50 óra? Ha valaki 50 óra birtokába kerül, mivel tudná eltölteni ezt az időt? Milyen lehetőségek rejlenek 50 órában? Hogyan lehetne ezt okosan felhasználni?

Markos Valéria könyvének borítóját szemlélve születtek meg a kérdéseim, melyekre szerettem volna válaszokat kapni. Az Úton a felelós állampolgári lét felé. Az iskolai közösségi szolgálat közvetlen és közvetett hatásai címủ könyvét azért ajánlom, mert kérdéseimre ebben találtam válaszokat.

Visszatérve a könyv borítójához: ott egy ember látható, aki előtt hosszú, kacskaringós út áll. Az út kezdetén, az útszéleken magát látta, ahogy különböző helyzetekben tevékenykedik, helyt áll. Látta, amint felszedi a szemetet, ezzel óvva a környezetét; ahogy egy idős hölgynek segít vinni a bevásárló táskát; ételt ad egy rászoruló embernek; kutyákat sétáltat; segít egy testi fogyatékkal élő embernek. Ahogy tanulmányoztam a könyvborítót, rájöttem, mindezek a szituációk 50 óra leforgása alatt valósulhattak meg.

Ahogy a könyv címe is említi, az 50 óra a 2016-ban bevezetett középiskolás diákok közösségi szolgálat-teljesítési kötelezettsége. Bármely állami, önkormányzati, egyházi, civil vagy nonprofit szervezetnél elvégezhető, mellyel az intézmény együttműködési megállapodásban áll, és 2016 januárja óta ennek igazolása is az érettségi bizonyítvány kiadásának feltétele. A szerző a közösségi szolgálat teljesítésének hatásait kívánja bemutatni, illetve annak személyiségformáló és attitűdformáló szerepét.

Markos Valéria, a Debreceni Egyetem oktatója és kutatója, aki számos tanulmányában foglalkozik a fiatalok civil aktivitásával, e könyvében olyan célokat, feladatokat és értékeket közvetít témája kapcsán, amelyek a civil élettel kapcsolatos 21 . századi kihívások megoldásainak számos lehetőségére hívják fel a figyelmünket. A szerző 2019-ben szerezte meg a doktori fokozatát a neveléstudományok tudományág Debreceni Egyetem Humán Tudományok Doktori Iskolájában. A kötetbe foglalt

1 Markos Valéria 2020 Úton a felelös állampolgári lét felé. Az iskolai közösségi szolgálat közvetlen és közvetett hatásai. Debreceni Egyetem Kiadó, Debrecen. Oktatáskutatók Könyvtára, 10. kötet, 245 oldal. kutatás az Új Nemzeti Kiválóságok Programjának támogatásával készült. A szerző kilenc fejezeten át mutatja be az iskolai közösségi szolgálatot. A fejezetek az önkéntesség múltjáról és jelenéről, valamint az iskolai szolgálat neveléselméleti vonatkozásairól szólnak, illetve mindezt oktatáspolitikai kontextusban is bemutatja a szerző. Szót ejt az önkéntesség céljáról, később a különböző empirikus kutatások koncepcióját veti össze, majd bemutatja a Nyíregyházán jelenlévő iskolai közösségi szolgálat négy első évének tapasztalatait. Mindezek mellett végzős középiskolások szemszögéből kaphatunk átfogó képet a hazánkban is alkalmazott önkéntességre nevelésről. Utolsó fejezetében az olvasó elé tárja kutatása tanulságait és javaslatait, melyek tovább gondolásra ösztönöznek.

A kötet bevezető részében a szerző a téma aktualitására, fontosságára és annak újszerűségére hívja fel a figyelmet. E részből érdemes kiemelni azt a megállapítását, hogy az iskolai közösségi szolgálat bevezetése rendkívül szükségszerű beavatkozás volt. A szerző monológja olyan kutatási kérdésekre és problémákra világít rá, amelyekben számos lehetőség rejlik. Olyan lehetőségek, mint például a kapcsolati tőke bővítése, kapcsolatok kiépítése, pályaorientáció, munkalehetőség, önismeret fejlesztése, az egyén kompetenciáinak és attitűdjének fejlesztése. A kutatás problémája, hogy eléri-e az iskolai közösségi szolgálat a fentiekben említett célokat? E részben találjuk a könyv tartalmának értelmezéséhez legszükségesebb központi fogalmak szakirodalmi értelmezését és a mérésekkel kapcsolatos információkat. A szerző hivatkozik a ma elfogadott iskolai közösségi szolgálat törvényi szabályozására, illetve segéddokumentumaira is.

A második fejezetben a rendszerváltást követő magyarországi non-profit szektor fejlődését tárja elénk a Szerző, amit párhuzamba állít a hazai önkéntesség alakulásával. Hazánkban az önkéntesség fogalmát meghatározó kritériumok jelentősen befolyásolják az önkéntesek számát. Markos Valéria könyve jól szemlélteti, hogy a magyar társadalom az önkéntesség tekintetében jelentősen el van maradva az európai viszonyokhoz képest. A problémák bemutatása közben rávilágít a szükséges intézkedésekre is. 
Az oktatás terén is bemutatja a szerző az iskolai közösségi szolgálat előzményeit, illetve a program első hazai kutatásának eredményeivel is gazdagodhat az olvasó, melyből az derül ki, hogy vegyes tapasztalatokról számoltak be a megkérdezettek. Ennek ellenére a szerző mégis arra kíváncsi, milyen negatív tényezők állnak a tapasztalatok mögött, illetve ezen felül milyen megoldások járulhatnak a sikeresebb közösségi szolgálat működéséhez?

A kötet harmadik fejezetében az iskolai közösségi szolgálatot, mint pedagógiai módszert mutatja be a szerző. Nagyon érdekes, innovatív pedagógiai eszköz lehetőségek birtokába juthatunk, amelyek akár intézményi és szervezeti hálózatosodásra is teret adhatnak a 21. századi oktatás kihívásait tekintve.

A negyedik fejezetben a szerző bemutatja az oktatáspolitika és a társadalom viszonyulását a közösségi szolgálathoz, amelyből kiderülhet, milyen tényezők alapján vizsgálják az oktatásüggyel kapcsolatos változásokat; kiket nevezünk az oktatáspolitika aktorainak, illetve egy átfogó képet kaphatunk arról, hogyan alakítsák az oktatáspolitikát. Ha tovább olvassuk a kötet negyedik fejezetét, arra is fény derülhet, hogy az oktatáspolitikai érdekeket különböző szervezetek képviselik, ezek között a non-profit szervezetek oktatásában betöltött szerepének jelentőségével vet számot a szerző. Megtudhatjuk a „civil” társadalomelméleti-ideológiai meghatározását. Az elméletek és kutatási előzmények bemutatása után a könyv olyan kérdésekre keresi a választ, hogy milyen szerepet töltenek be az oktatásban az önkéntességre épülő szervezetek, s fóként, hogyan lehet civil aktivitásra nevelni az oktatásban résztvevő középiskolás diákokat az oktatási rendszer keretein belül? Emellett a könyv olvasása során párhuzamba állíthatjuk a kontinentális rendszerben és az atlanti rendszerben megvalósuló civil aktivitás oktatását és jellemzőit is.

Nagyon érdekesen mutatja be Markos a Servicelearning és a Community-service programok adaptálását. Ezekkel az ismeretekkel elő is segíti az ötödik fejezet megértését, amelyben a szerző az iskolai közösségi szolgálat céljait tárja fel, melyeket két fódimenzióban határoz meg, azaz a társadalmi részvétel növekedésében és a pályaszocializáció elösegítésében. A szolgálat céljait nemzetközi és hazai szakirodalom alapján is megvizsgálja.

A hatodik fejezetben a közösségi szolgálattal foglalkozó kutatás bemutatására kerül sor. Az olvasó érdeklődve követheti a kutatási kérdések és az ezekre épülő hipotézisek részletes bemutatását.
Ki kell emelni, hogy Markos kutatása nemzetközi viszonylatban is újszerű, hiszen szükségesnek tartotta a szociokulturális, a környezeti és az egyéni tényezők befolyásoló hatásukat megvizsgálva megközelíteni a közösségi szolgálattal kapcsolatos attitűdöket. Az eddigi kutatásokkal nem szociológiai szempontú megközelítésre törekedtek, illetve nem voltak képesek ezt ötvözni neveléstudományi szempontú elemzéssel.

Mindezek mellett nagyon érdekes következtetésekre lehet szert tenni a hetedik fejezetben is, amely Nyíregyházában a 2015/2016-os tanévben induló, és az ezt követő négy évben kibontakozó iskolai közösségi szolgálat tapasztalatainak komplex leírásával találkozhatunk.

A könyv utolsó előtti fejezetében végzős középiskolások közösségi szolgálatuk során átélt tapasztalatairól olvashatunk. A szerző elénk tárja, hogy a közösségi szolgálat koncepciójának kidolgozásakor megfogalmazott célok hogyan és mennyire valósultak meg, illetve milyen hatást váltottak ki.

A kötet utolsó fejezetéhez érve érdekes és figyelemre méltó tanulságokat és javaslatokat fogalmaz meg a szerző azzal kapcsolatban, hogyan lehetne a közösségi szolgálat céljait minél hatásosabban megvalósítani. Markos javaslatai között szerepel a koordinációs irodák kialakítása, a szociális érzékenyítés fontossága, az alacsonyabb kulturális tőkével rendelkezők számára minél több olyan tevékenység, amik elősegítik a civil részvételük növekedését. A szerző úgy gondolja, érdemes lenne minél több egyházi intézményt is bevonni befogadó szervezetekként. A Szerző javaslatában szerepet kap a szülők bevonása, ezáltal a szülők kapcsolati tőkéje is növekedhetne. Érdemes azon is elgondolkodni, hogy Markos miért gondolja fontosnak az oktatási intézmények és szereplőinek motivációját és attitűdjét? Vajon ezek a tényezők hozzájárulhatnak a közösségi szolgálattal kapcsolatos pozitív attitűd kialakításához? Hogyan lehetne mindezt megvalósítani a gyakorlatban?

A könyv meggyőzo és reális képet ad a közösségi szolgálatról és sokoldalúan mutatja be működését, mely e kötetben két irányból válik fontossá: egyrészt mint pedagógiai program, másrészt mint olyan tevékenység, mely által a mai középiskolás fiatalok állampolgári aktivitása fejleszthető. Vizsgálja még a diákok élményeit és a tapasztalatokon alapuló tanulását, a kompetenciák és attitűdök fejlesztését és fejlődését. Markos Valéria kutatásának eredményei megalapozzák az iskolai közösségi szolgálat hazai továbbfejlesztésének lehetőségeit is. 
Szakmai meggyőződéssel ajánlom a könyvet a Magyarországon dolgozó összes középiskolai pedagógusnak, diáknak és a szülőknek egyaránt, továbbá az oktatáskutatóknak és az oktatáspolitikusoknak is, akik hasznos információkkal gazdagodhatnak a kutatási eredményeket, a tapasztalatokat és javaslatokat megismerve. Mindezek mellett érdemes eljuttatni a kötetet olyan szervezeteknek, akik lehetővé teszik, hogy a középiskolás diákok részesei legyenek az iskolai közösségi szolgálatnak. Külön ajánlom a könyvet az önkéntes-koordinátoroknak és önkéntes menedzsereknek, akik bővíthetik elméleti tudásukat, hogy a gyakorlatban még pontosabban végezhessék a munkájukat.
Személyesen is érintett vagyok a témában önkéntes koordinátor és önkéntes menedzserként. 2012-ben kezdtem a középiskolát és az iskolai közösségi szolgálat teljesítését. Így kerültem kapcsolatba az Egyesület a Társadalmi Tőke Fejlődéséért civil szervezettel, ahol nyolcadik éve önkénteskedem.

A könyv elolvasása során jó emlékeim idéződtek föl, ezért a könyv olvasásakor számos megállapítással, történettel tudtam azonosulni. Mit kaptam az iskolai közösségi szolgálattól? Elsősorban élményeket, lehetőségeket, barátokat, biztos kapcsolati tőkét, amit a nyolc éve folyamatosan bővítek; emellett fejlődést, tanulást, munkahelyet, elismerést is jelent számomra.

Kívánom a legtöbb középiskolás diáknak, hogy nyitott szívvel és szemmel járjanak, és tárják fel az 50 órában rejlő lehetőségeket! 